DOI: $10.31933 /$ JIMT

Received: 13 Juli 2020, Revised: 25 Agustus 2020, Publish: 21 September 2020

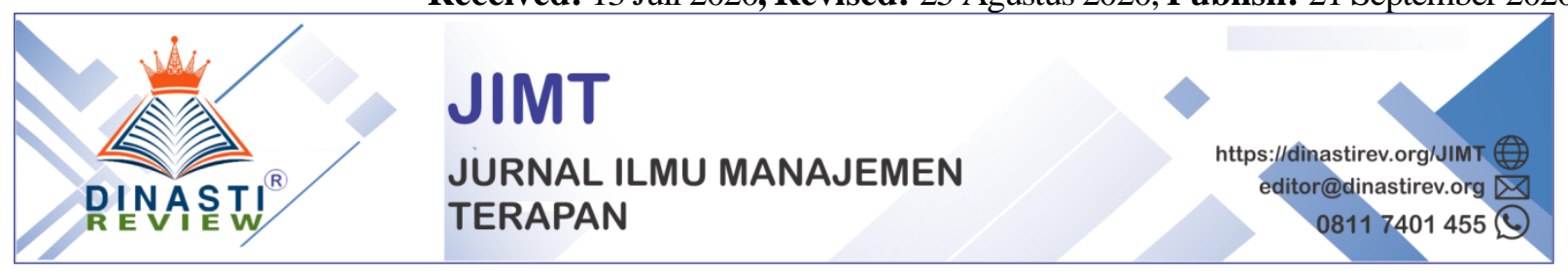

\title{
BEBERAPA FAKTOR YANG MEMPENGARUHI OPINI AUDIT GOING CONCERN
}

\author{
Apollo \\ Universitas Mercu Buana, Jakarta, Indonesia, apollo@mercubuana.ac.id
}

\section{Corresponding Author: First Author}

\begin{abstract}
Abstrak: Standar auditing selama 12 tahun terakhir mengalami peningkatan pada sisi kuantitas maupun kualitas. Kondisi ini mengindikasikan terjadinya kompleksitas peran auditor sebagai pihak yang independen dalam menciptakan good corporate governance. Terdapat dua faktor utama yang menyebabkan terjadinya skandal auditing yakni : (a) implementasi standar umum, dan (b) implementasi standar pekerjaan lapangan. Penelitian ini bertujuan memperoleh bukti empirik pengaruh solidaritas sosial, kompetensi auditor, profesionalisme auditor, dan reputasi perusahaan klien terhadap opini audit going concern. Untuk menguji fakta empirik tersebut diperlukan susunan logika dengan Background Theory: Teori Idealisme Klasik, Grand Theory : General Equilibrium Theory - IO Wassily Leontief (1906 - 1999) Standar Auditing (2011), Middle Range Theory : Posmodernisme Derrida (19302004), Rorty (1931-2007), Sartre (1905-1980), dan Application Theory : Agency Theory : Jensen \& Meckling (1976); Francis and Smith (1994); Hammer (1992) Kamin \& Ronen (1978); Fama (1980); Baiman(1982); Caose (1987); Zimmerman (1980). Unit penelitian adalah 84 responden pada Kantor Akuntan Publik Big Four di Jakarta. Metode alat analisis menggunakan path analysis dan regresi untuk mengetahui pengaruh secara parsial maupun simultan. Hasil penelitian setelah dilakukan uji validitas, reabilitas, dan transformasi data ordinal ke data interval menunjukan hasil: (a) solidaritas sosial, kompetensi auditor, profesionalisme auditor secara parsial tidak berpengaruh signifikan dengan opini audit going concern, sedangkan reputasi perusahaan klien berpengaruh signifikan terhadap opini audit going concern, dan (b) solidaritas sosial, kompetensi auditor, profesionalisme auditor, reputasi perusahaan klien terhadap opini audit going concern secara simultan berpengaruh positif dan signifikan sebesar nilai adjusted $\mathrm{R}$ square 0.626 atau sebesar $62.6 \%$ sedangkan sisanya $37.4 \%$ dipengaruhi variabel lain di luar model penelitian. Hasil penelitian ini mempunyai konsistensi dengan seluruh kerangka pemikiran, tinjauan pustaka, dan penelitian terdahulu. Adapun saran untuk penelitian: (a) bagi pengembangan ilmu auditing diperlukan penelititan lanjutan di luar model seperti budaya, tanggung jawab etika auditor, (b) untuk kebijakan IAPI dan KAP perlu menyusun kejelasan maupun kriteria lebih konkrit pemberian opini audit going concern, pertimbangan solidaritas sosial, peningkatan kompetensi auditor, memperbaiki profesionalisme auditor, dan memperhatikan kemampuan reputasi perusahaan klien sebagai pihak auditee.
\end{abstract}

Kata Kunci: Solidaritas Sosial, Kompetensi Auditor, Profesionalisme Auditor, Reputasi Perusahaan Klien, Opini Audit Going concern, KAP Big Four

\section{PENDAHULUAN}

Praktik akuntansi di dominasi oleh : (1) Securities and Exchange Commission (SEC), (2) American Institute of Certified Public Accountant (AICPA), (3) Financial Accounting Standard Board (FASB), (4) Govermental Accounting Standard Board (GASB), (5) International 
Financial Reporting Standard (IFRS) tahun 2012, (6) Standar Akuntansi Keuangan (IAI), (7) keluarnya Sarbanes-Oxley Act of 2002, Public Company Accounting Reform and Investor Protection Act of 2002) sebagai hukum federal Amerika Serikat yang ditetapkan pada 30 Juli 2002 terhadap sejumlah skandal akuntansi perusahaan besar yang termasuk di antaranya melibatkan Enron. Skandal-skandal akuntansi yang menyebabkan kerugian bilyunan dolar bagi investor karena merosotnya harga saham perusahaan-perusahaan publik. Pengalaman pada kasus PT. Adaro Energy, Tbk dalam skandal rencana initial public offering (IPO) terbesar di BEI dengan target (Rp 12,3 triliun), enam kali lebih mahal book value, tapi (rill atau kecurangan) PT. Adaro Energy, atas dugaan tranfer pricing melalui afiliasi, dan perusahaan afiliasi menjual lagi harga mahal, sehingga pemegang saham (stockholders) mendapat keuntungan 10 kali, dengan tax saving (jual murah pajak kecil). Kasus Temasek menguasai 89\% perusahaan Telkomonikasi di Indonesia (induk perusahaan STT), memilki 75\% saham Asian Mobile Holding (AMH), selanjutnya (AMH) menjual sahamnya di Indosat 40,8 \% (Rp 17 triliun) ke Qtel (Qatar telecom), dan Singapore Technologies Telemedia Pte Ltd. Yang masih dalam proses di MA dan belum berkekuatan hukum tetap. Puncaknya skandal akuntansi terjadi pada skandal Enron, WorldCom, Xerox, dan Merck, PT Telkom, PT Kerta Api Indonesia, Lippo Bank (CMB Niaga), sebagai representasi pertentangan kepentingan, sekaligus kegagalan praktik akuntansi dan auditing yang disusun berdasarkan paradigma ilmu.

Kasus kecurangan akuntansi ini dapat dipahami bila dikaitkan dengan melakukan refleksi moral atas perilaku atau tindakan manusia dalam bisnis (=etika bisnis), sebagai akibat memaksimalkan kenikmatan (=hedonisme). Etika (=budi) selalu menyangkut kebaikan manusia sebagai manusia. Setiap manusia selalu ingin berupaya untuk menjadi orang baik dalam segala dimensinya, termasuk dalam bisnis. Manusia memerlukan budi (= suara hati) agar hidupnya lestari (= luhur). Etika diperlukan manusia agar hidupnya teratur, bermutu, dan bermakna. Pada tatanan ini globalisasi menempatkan nilai aksiologi.

Berikut ini adalah daftar tentang skandal akuntansi di beberapa negara maju sebagai kiblat akuntansi. Tabel ini mengindikasikan peningkatan kegagalan praktik akuntansi, baik segi kuantitas maupun kualitasnya.

Tabel. 1 Skandal Akuntansi Di Beberapa Negara

\begin{tabular}{|l||l|l|l|l|}
\hline Company & Year & Audit Firm & Country & Notes \\
\hline \hline Cendant & 1998 & Ernst \& Young & $\begin{array}{l}\text { United } \\
\text { States }\end{array}$ & \\
\hline \hline Microstrategy & 2000 & $\begin{array}{l}\text { PricewaterhouseCo } \\
\text { opers }\end{array}$ & $\begin{array}{l}\text { United } \\
\text { States }\end{array}$ & Michael Saylor \\
\hline \hline Computer Associates & 2000 & KPMG & $\begin{array}{l}\text { United } \\
\text { States }\end{array}$ & Sanjay Kumar \\
\hline \hline Xerox & 2000 & KPMG & $\begin{array}{l}\text { United } \\
\text { States }\end{array}$ & Falsifying financial results \\
\hline \hline One.Tel & 2001 & Ernst \& Young & Australia & \\
\hline \hline Enron & 2001 & Arthur Andersen & $\begin{array}{l}\text { United } \\
\text { States }\end{array}$ & $\begin{array}{l}\text { Jeffrey Skilling, Kenneth } \\
\text { Lay, Andrew Fastow }\end{array}$ \\
\hline \hline Adelphia & 2002 & Deloitte \& Touche & United & John Rigas \\
\hline
\end{tabular}




\begin{tabular}{|c|c|c|c|c|}
\hline Company & Year & Audit Firm & Country & Notes \\
\hline & & & States & \\
\hline $\mathrm{AOL}$ & 2002 & Ernst \& Young & $\begin{array}{l}\text { United } \\
\text { States }\end{array}$ & Inflated sales \\
\hline Bristol-Myers Squibb & 2002 & \begin{tabular}{|l|} 
PricewaterhouseCo \\
opers
\end{tabular} & $\begin{array}{l}\text { United } \\
\text { States }\end{array}$ & Inflated revenues \\
\hline CMS Energy & 2002 & Arthur Andersen & $\begin{array}{l}\text { United } \\
\text { States }\end{array}$ & Round trip trades \\
\hline Duke Energy & 2002 & Deloitte \& Touche & $\begin{array}{l}\text { United } \\
\text { States }\end{array}$ & Round trip trades \\
\hline Dynegy & 2002 & Arthur Andersen & $\begin{array}{l}\text { United } \\
\text { States }\end{array}$ & Round trip trades \\
\hline El Paso Corporation & 2002 & $\|$ Deloitte \& Touche & $\begin{array}{l}\text { United } \\
\text { States }\end{array}$ & Round trip trades \\
\hline Global Crossing & 2002 & Arthur Andersen & Bermuda & $\begin{array}{l}\text { Network capacity swaps } \\
\text { to inflate revenues }\end{array}$ \\
\hline Halliburton & 2002 & Arthur Andersen & $\begin{array}{l}\text { United } \\
\text { States }\end{array}$ & $\begin{array}{l}\text { Improper booking of cost } \\
\text { overruns }\end{array}$ \\
\hline ImClone Systems & 2002 & KPMG & $\begin{array}{l}\text { United } \\
\text { States }\end{array}$ & Samuel D. Waksal \\
\hline Kmart & 2002 & \begin{tabular}{|l|} 
PricewaterhouseCo \\
opers
\end{tabular} & $\begin{array}{l}\text { United } \\
\text { States }\end{array}$ & $\begin{array}{l}\text { Misleading accounting } \\
\text { practices }\end{array}$ \\
\hline Merrill Lynch & 2002 & Deloitte \& Touche & $\begin{array}{l}\text { United } \\
\text { States }\end{array}$ & Conflict of interest \\
\hline Peregrine Systems & 2002 & KPMG & $\begin{array}{l}\text { United } \\
\text { States }\end{array}$ & Overstated sales \\
\hline Reliant Energy & 2002 & Deloitte \& Touche & $\begin{array}{l}\text { United } \\
\text { States }\end{array}$ & Round trip trades \\
\hline Tyco International & 2002 & \begin{tabular}{|l|} 
PricewaterhouseCo \\
opers
\end{tabular} & Bermuda & $\begin{array}{l}\text { Improper accounting, } \\
\text { Dennis Kozlowski }\end{array}$ \\
\hline WorldCom & 2002 & Arthur Andersen & $\begin{array}{l}\text { United } \\
\text { States }\end{array}$ & $\begin{array}{l}\text { Overstated cash flows, } \\
\text { Bernard Ebbers }\end{array}$ \\
\hline Royal Ahold & 2003 & Deloitte \& Touche & Netherlands & $\begin{array}{l}\text { Inflating promotional } \\
\text { allowances }\end{array}$ \\
\hline $\begin{array}{l}\text { HealthSouth } \\
\text { Corporation }\end{array}$ & 2003 & Ernst \& Young & $\begin{array}{l}\text { United } \\
\text { States }\end{array}$ & Richard M. Scrushy \\
\hline AIG & 2004 & \begin{tabular}{|l|} 
PricewaterhouseCo \\
opers
\end{tabular} & $\begin{array}{l}\text { United } \\
\text { States }\end{array}$ & $\begin{array}{l}\text { Accounting of structured } \\
\text { financial deals }\end{array}$ \\
\hline Anglo Irish Bank & 2008 & Ernst \& Young & Ireland & Anglo Irish Bank hidden \\
\hline
\end{tabular}




\begin{tabular}{|l||l||l|l|l|}
\hline Company & Year & Audit Firm & Country & Notes \\
\hline \hline & & & & loans controversy \\
\hline $\begin{array}{l}\text { Satyam Computer } \\
\text { Services }\end{array}$ & 2009 & $\begin{array}{l}\text { PricewaterhouseCo } \\
\text { opers }\end{array}$ & India & Falsified accounts \\
\hline
\end{tabular}

Sumber: Wikipedia,_encyclopedia di olah kembali

Tabel 2. Corporate Scandals

\begin{tabular}{|c|c|c|c|c|}
\hline \multicolumn{5}{|c|}{ List of the Company's Name Involved in Scandal } \\
\hline $\begin{array}{l}\text { HP Spying } \\
\text { Scandal }\end{array}$ & Bre-X & Dynegy & $\begin{array}{l}\text { Hafskip's } \\
\text { collapse }\end{array}$ & Lernout \& Hauspie \\
\hline $\begin{array}{l}\text { Siemens } \\
\text { Scandal }\end{array}$ & $\begin{array}{l}\text { Bristol- } \\
\text { Myers } \\
\text { Squibb }\end{array}$ & $\begin{array}{l}\text { El Paso } \\
\text { Corp }\end{array}$ & Halliburton & Livedoorscandal \\
\hline $\begin{array}{l}\text { American } \\
\text { Airlines }\end{array}$ & $\begin{array}{l}\text { Carrian } \\
\text { Group }\end{array}$ & $\begin{array}{c}\text { Enron } \\
\text { accounting } \\
\text { fraud }\end{array}$ & $\begin{array}{l}\text { Harken Energy } \\
\text { Scandal }\end{array}$ & $\begin{array}{l}\text { Long-Term Capital } \\
\text { Management - LTCM }\end{array}$ \\
\hline Adelphia & Clearstream & Exxon & HealthSouth & $\begin{array}{l}\text { Merck Medicaid fraud } \\
\text { investigation }\end{array}$ \\
\hline $\begin{array}{l}\text { AOL Time } \\
\text { Warner }\end{array}$ & $\begin{array}{c}\text { Chiquita } \\
\text { Brands } \\
\text { International }\end{array}$ & $\begin{array}{l}\text { Fannie } \\
\text { Mae }\end{array}$ & Homestore.com & Niccor Energy \\
\hline $\begin{array}{c}\text { Arthur } \\
\text { Andersen }\end{array}$ & $\begin{array}{c}\text { CMS } \\
\text { Energy }\end{array}$ & $\begin{array}{l}\text { Firestone } \\
\text { Tire and } \\
\text { Rubber } \\
\text { Company }\end{array}$ & IG Farben & Olympus Scandal \\
\hline $\begin{array}{c}\text { BAE } \\
\text { Systems }\end{array}$ & $\begin{array}{l}\text { Compass } \\
\text { Group }\end{array}$ & FlowTex & $\begin{array}{c}\text { Kerr-McGee, } \\
\text { the Karen } \\
\text { Silkwood case }\end{array}$ & Nortel \\
\hline $\begin{array}{c}\text { Bank of } \\
\text { Credit and } \\
\text { Commerce } \\
\text { International }\end{array}$ & $\begin{array}{l}\text { Corrib gas } \\
\text { controversy } \\
\text { Kilcommon, } \\
\text { Erris, Co. } \\
\text { Mayo, } \\
\text { Ireland }\end{array}$ & Ford Pinto & $\begin{array}{l}\text { Kinney } \\
\text { National } \\
\text { Company }\end{array}$ & Mirant \\
\hline $\begin{array}{l}\text { Barings } \\
\text { Bank }\end{array}$ & $\begin{array}{l}\text { Deutsche } \\
\text { Bank }\end{array}$ & $\begin{array}{l}\text { Global } \\
\text { Crossing }\end{array}$ & Kmart & Parmalat \\
\hline Bayer & $\begin{array}{l}\text { Duke } \\
\text { Energy }\end{array}$ & $\begin{array}{l}\text { Guinness } \\
\text { affair }\end{array}$ & Krupp & Rite Aid \\
\hline
\end{tabular}

Sumber: Wikipedia, the free encyclopedia di olah kembali

Pada tabel 1 dan 2 dapat disimpulkan pada aspek aksiologi akuntansi yakni menyangkut kegunaan ilmu (= sains), sebagai penciri persatuan alam, manusia, dan Tuhan. Teori Utilitarian, 
oleh John Stuart Mill (1806-1873), dengan prinsip memaksimalkan rasa enak (bernilai) dan meminimalkan rasa sakit (tidak enak). Dasar pemikiran ini merupakan pangkal penelitian dan kajian dalam bidang ilmu ekonomi. Selanjutnya pendapat ini dikritik Bentham sebagai etika Babi (model saldo nikmat kurangi sakit). Betham mengusulkan etika dengan proposisi baru "the greatest happiness for the great number" (= kebahagiaan yang besar mungkin bagi jumlah yang terbesar mungkin). yang dijelaskan dalam dua tahapan nikmat (pleasure) dan perasaan sakit (pain). Manusia rasional selalu memiliki kecenderungan memaksimalkan rasa nikmat (laba) dan meminimalkan rasa sakit (= kerugian atau biaya). Lebih lanjut Mill dalam Frans Magnis Suseno (1997:180) menyatakan tujuan tindakan moral manusia adalah memaksimalkan perasaan nikmat dan meminimalisasikan perasaan sakit (menghindari perasaan tidak enak). Mill membuat prinsip kegunaan (utilitarisme) yaitu bertitik tolak pada situasi di mana kita berhadapan dengan berbagai kemungkinan untuk bertindak dari alternatif mana yang kita pilih dan mempunyai nilai paling menguntungkan. Hal ini disebut hedoisme psikologis yaitu prinsip mencari kebahagiaan sebesarbesarnya. Apa yang dikemukakan Mill merupakan embrio agency theory, yang dipakai dalam penelitian ini. Teori Utilitarian dapat dijelaskan dalam ilmu ekonomi-akuntansi dengan pendekatan deduktif dan induktif (apriori-aposterori) melalui nilai-nilai egositik, materialistik (uang), utililarian yang diekpresikan dalam laporan keuangan. Laporan keuangan perusahaan menunjukkan sifat egoistik (kepentingan) stakeholders untuk memperoleh bagian manfaat atau keuntungan yang menjadi haknya. Pada sisi ini akan muncul nilai Utilitarian, dengan sebuah gagasan nilai suatu tindakan dinyatakan berguna apabila memenuhi syarat perbuatan "memaksimalkan kenikmatan (=laba/profit), dan meminimalkan sakit (= rugi/biaya)", tanpa memandang prosesnya (tanpa nilai-nilai etika yang baik "good ethics, and good business").

Tanggung jawab dan kewajiban auditor berkaitan dengan pandangan Positive Accounting Theory" Watts dan Zimmarman (1986) dan "Agency Theory" oleh Jensen Meckling (1976) sebagai bidang akuntansi (=sisi mikro ekonomi) munculnya situasi konflik dan pertentangan kepentingan, sebagai representasi pertentangan kepentingan dalam perusahaan antara manajemen, pemegang saham, kreditor, pemerintah, karyawan perusahaan, pemasok, konsumen, dan masyarakat umum secara sempit pertentangan kepentingan disebut antara agent dan principal. Dengan demikian tugas auditor adalah keberanian memberikan opini berdasarkan pertimbangan moral tentang kebaikan bagi masyarakat. Pada sisi lain pengawasan pada kelangsungan hidup perusahaan dilakukan oleh principles terhadap agent melalui biaya monitoring dengan penggunaan jasa audit pihak eksternal.

Urgensi latar belakang penelitian kedua adalah skeptisme model Bacon disejajarkan dengan ilmu akuntansi dan auditing saat ini mencapai anomali, dan krisis dilakukan dengan (a) Idola tribus manusia menarik simpulan tanpa dasar secukupnya; dangkal, tidak memadai, (b) Idola specus simpulan berdasarkan prasangka, selera apriori, (c) Idola fori/pasar mengikuti selera publik, umum yang simpulan belum tentu benar, (d) Idola theatri berdasarkan dogmatis, mitos, gaib, realitas dunia adalah palsu. Kemudian Mill menganjurkan Logika Induksi sebagai lingkaran setan (petitio) simpulan dalam premis, premis bertumpu pada empirik. Karena itu model akuntansi dan auditing harus menggunakan model lebih luas dalam bidang sosiologi, psikologi atau kemampuan ilmu akuntansi berdialog dengan ilmu lainnya. Argumentasi dalam Skeptis-Metodis dikenal dengan istilah (a) Ren'e Descartes (1596-1650) Aku berpikir maka aku ada (=Cogito ergo sum), (b) Santo Agustinus (354-430), kalau aku keliru itu berarti saya ada (="Si fallor, sum,"), (c) Maine de Biran (1766 - 1824), Saya Merasa, Maka Saya Ada (=Volo, ergo sum) sehingga sampai kepada Kant (1724-1804), kebaikan tertinggi (summum bonum). 
Dengan menggunakan dua urgensi tersebut dapat dipaparkan tentang keberanian auditor memberikan opini audit going concern berdasarkan fakta dan integritas pasti ditentukan beberapa faktor. Dengan paradigma deduksi ada empat faktor: (a) Solidaritas Sosial, (b) Kompetensi Auditor, (c) Profesionalisme Auditor, dan (d) Reputasi Perusahaan Klien.

Berdasarkan kondisi-kondisi yang telah diuraikan pada bagian sebelumnya, dapat diperoleh gambaran latar belakang situasional, kondisional serta empirik mengenai faktor-faktor yang mempengaruhi opini audit going concern dirumuskan tema sentral sebagai berikut :

"walaupun belum jelas faktor yang mempengaruhi opini audit going concern pada KAP Big Four di Jakarta, namun terdapat kecenderungan awal solidaritas sosial, kompetensi auditor, profesionalisme auditor, reputasi perusahaan klien mempengaruhi opini audit going concern. Karena itu diperlukan penelitian secara empirik pada KAP di Jakarta dalam rangka memperoleh kejelasan fenomena ini”

1. Kajian Literatur, dan Kerangka Pemikiran

1.1 Solidaritas Sosial memiliki konstrak variabel solidaritas sosial menurut Karl Marx (1818-1883), Emile Durkheim (1858-1917), Herbert Spencer (1820-1903), Marx Weber (1864-1920) untuk dijabarkan dalam operasionalisasi variabel dan kuesioner, memiliki dimensi yaitu keterikatan bersama dapat diukur dengan menggunakan beberapa indikator, meliputi: (a) pertimbangan moral, (b) kepercayaan terhadap klien, dan (c) pengalaman bersama klien.

1.2 Kompetensi Auditor, menurut Spencer and Spencer (1993) ada lima karakteristik pembentuk kompetensi, yaitu watak, motif, konsep diri, pengetahuan dan keterampilan. Dua karakteristik yang disebut terakhir cenderung kelihatan karena ada di permukaan, sedangkan tiga karakteristik lainnya lebih tersembunyi dan relatif sulit dikembangkan, meskipun berperan sebagai sumber kepribadian. Terdapat lima macam karakteristik kompetensi (five characteristics of competency) motives, traits, self-concept, knowledge, skill. Ontologi tentang kompetensi sebenarnya berasal pada teori pembentukan pribadi yakni teori psikoanalitik Sigmund Freud (1923), kepribadian ini terdiri tiga elemen, yaitu id, ego, dan super-ego. Ketiga kepribadian inilah yang bekerja sama untuk menciptakan bentuk-bentuk perilaku manusia yang kompleks. Secara episteme bidang motivasi dan kompetensi adalah theoria Abraham H. Maslow (1908-1970), Douglas McGregor (1906-1964), Frederick Herzberg (1966), Victor Vroom Model (1964), Clayton Alderfer, Model David McClelland's, dan Model Spencer and Spencer (1993); Dengan demikian dapat disimpulkan konstrak variabel kompetensi auditor menurut Douglas McGregor (1906-1964), Abraham H. Maslow (1908-1970), Victor Vroom (1964), Frederick Herzberg (1966), Spencer and Spencer (1993), Murtanto, dan Gudono (1999:40) untuk dijabarkan dalam operasionalisasi variabel dan kuesioner, antara lain : (1) knowledge component, (2) psychological traits, (3) cognitive abilities, (4) decision strategies, dan (5) task analysis dapat diukur dengan menggunakan beberapa indikator, meliputi : (a) pengetahuan umum dan khusus, (b) memperoleh fakta-fakta yang relevan, (c) tanggung jawab, (d) kemampuan bekerja sama, (e) mampu berpikir secara sistematis, (f) memiliki kemampuan analisis, (g) objektifitas pengambilan 
keputusan, (h) independensi pengambilan keputusan, (i) skeptisme yang profesional, serta (j) kemampuan teknis yang memadai.

1.3 Profesionalisme Auditor; Menurut Kalbers, dan Fogarty (1995:72) sebagai profesional, akuntan publik mengakui tanggung jawabnya terhadap masyarakat, terhadap klien, dan terhadap rekan seprofesi, termasuk untuk berperilaku yang terhormat, sekalipun ini merupakan pengorbanan pribadi. Dengan demikian dapat disimpulkan konstrak variabel profesionalisme auditor menurut Hall (1968), Kalbers, dan Fogarty (1995:72), SPAP (2011) untuk dijabarkan dalam operasionalisasi variabel dan kuesioner yang memiliki dimensi, antara lain : (1) pengabdian terhadap profesi, (2) kewajiban sosial, (3) kemandirian, (4) keyakinan terhadap profesi, (5) dan hubungan dengan rekan seprofesi dapat diukur dengan menggunakan beberapa indikator, meliputi: (a) tetap teguh pada profesi auditor, (b) menggunakan pengetahuan, kemampuan dan pengalaman, (c) profesi auditor mampu menjaga kekayaan negara dan masyarakat, (d) profesi auditor menjadi satu-satunya profesi yang menciptakan transparansi, (e) pernyataan pendapat atas laporan keuangan tidak mendapat tekanan dari siapapun, (f) mendapat kepuasan sebagai auditor, serta (g) organisasi auditor.

1.4 Reputasi Perusahaan Klien. Barney (1991:443) mengatakan reputasi merupakan salah satu elemen kunci intangible resource yang akan menjadi sumber penciptaan kondisi keunggulan daya saing berkelanjutan (sustainable competitive advantage) suatu perusahaan. Konstrak variabel reputasi perusahaan klien menurut Spencer (1974:90), Barney (1991:443), Hannon (1992:190), Larkin (2003;117), dll untuk dijabarkan dalam operasionalisasi variabel dan kuesioner yang memiliki dimensi, antara lain : (1) kredibilitas, (2) kecakapan manajerial, dan (3) kecakapan berkomunikasi dapat diukur dengan menggunakan beberapa indikator, meliputi: (a) tingkat kepatuhan karyawan pada CEO, (b) tingkat kengganan dan resistensi terhadap CEO, (c) keterlibatan dalam masalah hukum, (d) frekwensi CEO mendapat teguran tertulis, (e) aktivitas sosial CEO, (f) jabatan dalam organisasi, (g) tingkat kepentingan visi, misi, bagi CEO, (h) cara penyusunan visi, misi, dan strategi bagi CEO, (i) kesesuaian implementasi program-program dengan visi, misi, (j) pencanangan program pencapaian visi, misi, (k) alat ukur target yang jelas dalam manajemen, (1) peningkatan harga saham setelah IPO, (m) efektivitas CEO memimpin RUPS, (n) sosialisasi visi dan misi oleh CEO, (o) tingkat pemahaman karyawan pada visi dan misi, (p) penjelasan pertanggungjawaban CEO pada RUPS, (q) exposure CEO di media masa.

1.5 Opini Audit Going Concern; Auditor memiliki suatu tanggung jawab untuk mengevaluasi status kelangsungan hidup perusahaan dalam setiap pekerjaan auditnya. Mengacu kepada Statement On Auditing Standard No. 59 (AICPA, 1988), auditor harus memutuskan apakah mereka yakin perusahaan klien akan bisa bertahan di masa yang akan datang. PSA 29 paragraf 11 huruf d menyatakan keragu-raguan yang besar tentang kemampuan satuan usaha untuk mempertahankan kelangsungan hidupnya (going concern) merupakan keadaan yang mengharuskan auditor menambahkan paragraf penjelasan (atau bahas penjelasan lain) dalam laporan audit, meskipun tidak mempengaruhi pendapat wajar tanpa pengecualian (unqualified opinion), yang dinyatakan oleh auditor. Dengan demikian dapat disimpulkan konstrak variabel opini audit going concern menurut Chen, dan Church (1992), Arens (1997), 
Indira, dan Ella (2008), SPAP 2011, untuk dijabarkan dalam operasionalisasi variabel dan kuesioner yang memiliki dimensi, yaitu tanggung jawab auditor dapat diukur dengan menggunakan beberapa indikator, meliputi : (a) kemampuan entitas dalam mempertahankan kelangsungan hidup, dan (b) ketidakpastian siginifikan atas kelangsungan hidup entitas;

\subsection{Kerangka Pemikiran:}

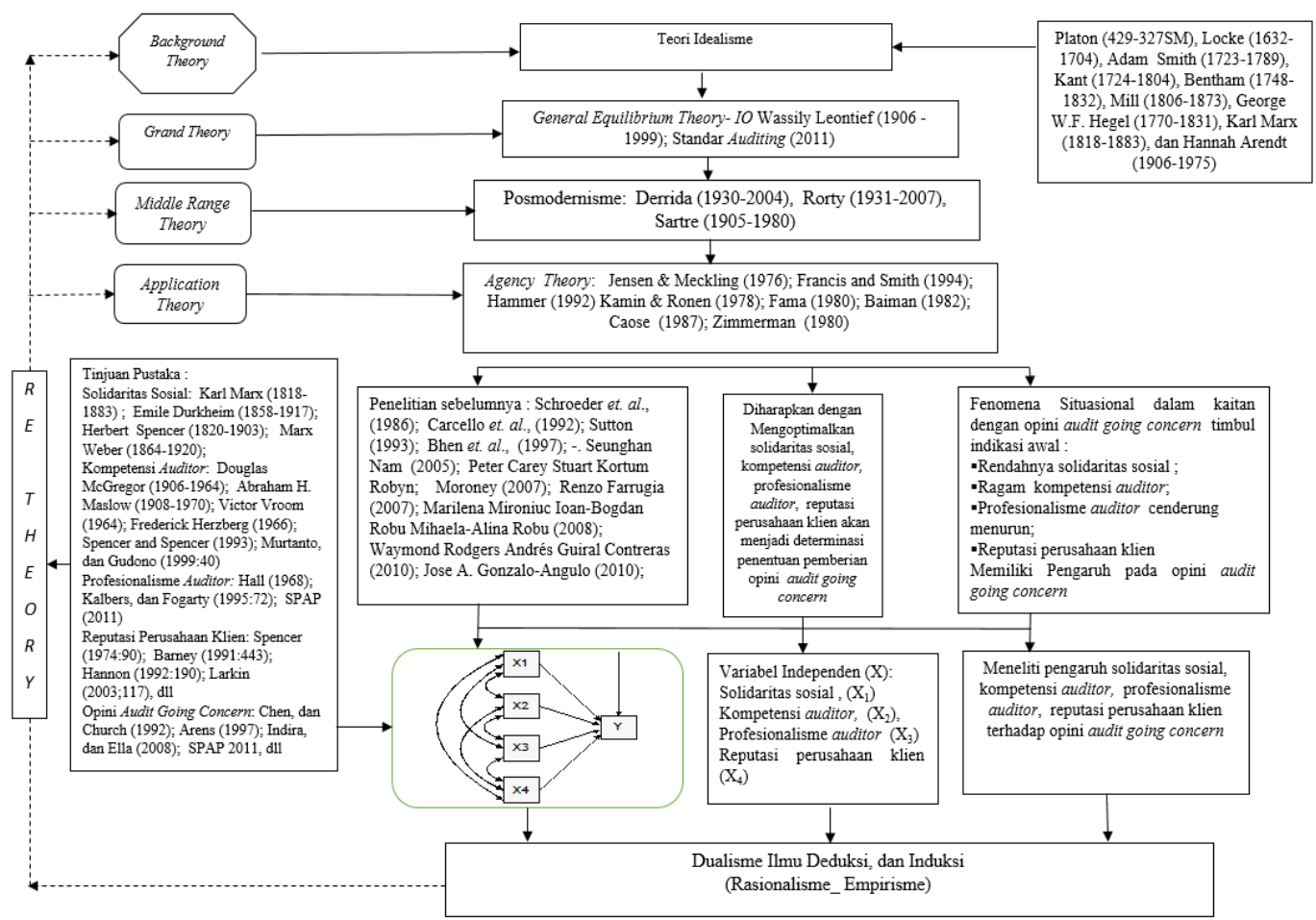

Gambar 1. Kerangka Pemikiran

\section{METODE PENELITIAN}

Penelitian ini adalah verifikatif research atau bertujuan memperoleh kejelasan hubungan/pengaruh variabel dalam menguji hipotesis atau disebut explanatory (Zikmund, 1997). Penelitian ini menggunakan 4 variabel untuk menjelaskan Opini Audit Going Concern.

\section{Measurement}

Adapun objek penelitian ini adalah: "solidaritas sosial $\left(\mathrm{X}_{1}\right)$, kompetensi auditor $\left(\mathrm{X}_{2}\right)$, profesionalisme auditor $\left(\mathrm{X}_{3}\right)$, reputasi perusahaan klien $\left(\mathrm{X}_{4}\right)$, dan opini audit going concern (Y)"'. Variabel tersebut dijabarkan dalam sub variabel atau dimensi, sedangkan dimensi akan dijabarkan lagi dalam indikator-indikator penelitian dalam skala ordinal dan di susun kuesionernya.

Tabel 3 Operasionalisasi Variabel

\begin{tabular}{|c|c|c|c|l|c|}
\hline Variabel & Dimensi & Indikator & Item & Skala & Sumber Data \\
\hline Solidaritas Sosial & Keterikatan & Pertimbangan & $1-2$ & Ordinal & Kuesioner \\
\hline
\end{tabular}




\begin{tabular}{|c|c|c|c|c|c|}
\hline Variabel & Dimensi & Indikator & Item & Skala & Sumber Data \\
\hline \multirow{3}{*}{$\begin{array}{c}\left(\mathrm{X}_{1}\right) \text {; Durkheim } \\
(1986: 181), \\
\text { Karl Marx (1818- } \\
\text { 1883), Herbert } \\
\text { Spencer (1820- } \\
\text { 1903), Marx Weber } \\
(1864-1920) \\
\end{array}$} & \multirow[t]{3}{*}{ bersama } & moral & & & \\
\hline & & $\begin{array}{l}\text { Kepercayaan } \\
\text { terhadap klien }\end{array}$ & $3-5$ & Ordinal & Kuesioner \\
\hline & & $\begin{array}{l}\text { Pengalaman } \\
\text { bersama klien }\end{array}$ & $6-8$ & Ordinal & Kuesioner \\
\hline \multirow{10}{*}{$\begin{array}{l}\text { Kompetensi Auditor } \\
\quad\left(\mathrm{X}_{2}\right) \\
\text { Douglas McGregor } \\
\text { (1906-1964), } \\
\text { Abraham H. Maslow } \\
(1908-1970), \\
\text { Victor Vroom } \\
(1964), \\
\text { Frederick Herzberg } \\
\text { (1966), Spencer and } \\
\text { Spencer (1993) }\end{array}$} & \multirow[t]{2}{*}{$\begin{array}{l}\text { Knowledge } \\
\text { Component }\end{array}$} & $\begin{array}{l}\text { Pengetahuan umum } \\
\text { dan khusus }\end{array}$ & $9-10$ & Ordinal & Kuesioner \\
\hline & & $\begin{array}{l}\text { Memperoleh fakta- } \\
\text { fakta yang relevan }\end{array}$ & 11 & Ordinal & Kuesioner \\
\hline & \multirow{2}{*}{$\begin{array}{c}\text { Psychological } \\
\text { traits }\end{array}$} & Tanggung jawab & 12 & Ordinal & Kuesioner \\
\hline & & $\begin{array}{l}\text { Kemampuan } \\
\text { bekerja sama }\end{array}$ & 13 & Ordinal & Kuesioner \\
\hline & \multirow[t]{2}{*}{$\begin{array}{l}\text { Cognitive } \\
\text { abilities }\end{array}$} & $\begin{array}{l}\text { Mampu berpikir } \\
\text { secara sistematis }\end{array}$ & 14 & Ordinal & Kuesioner \\
\hline & & $\begin{array}{l}\text { Memiliki } \\
\text { kemampuan analis }\end{array}$ & 15 & Ordinal & Kuesioner \\
\hline & \multirow[t]{2}{*}{$\begin{array}{l}\text { Decision } \\
\text { strategies }\end{array}$} & $\begin{array}{l}\text { Objektifitas } \\
\text { pengambilan } \\
\text { keputusan }\end{array}$ & 16 & Ordinal & Kuesioner \\
\hline & & $\begin{array}{l}\text { Independensi } \\
\text { pengambilan } \\
\text { keputusan }\end{array}$ & 17 & Ordinal & Kuesioner \\
\hline & \multirow[t]{2}{*}{ Task analysis } & $\begin{array}{l}\text { Skeptisme yang } \\
\text { profesional }\end{array}$ & 18 & Ordinal & Kuesioner \\
\hline & & $\begin{array}{l}\text { Kemampuan teknis } \\
\text { yang memadai }\end{array}$ & 19 & Ordinal & Kuesioner \\
\hline \multirow{4}{*}{$\begin{array}{c}\text { Profesionalisme } \\
\text { Auditor } \\
\left(\mathrm{X}_{3}\right) \\
\text { Hall } \\
(1968: 95), \\
\text { Kalbers, dan Fogarty } \\
\text { (1995:72), SPAP } \\
(2011)\end{array}$} & \multirow[b]{2}{*}{$\begin{array}{c}\text { Pengabdian } \\
\text { terhadap } \\
\text { profesi }\end{array}$} & $\begin{array}{l}\text { Tetap teguh pada } \\
\text { profesi auditor }\end{array}$ & 20 & Ordinal & Kuesioner \\
\hline & & $\begin{array}{l}\text { Menggunakan } \\
\text { pengetahuan, } \\
\text { kemampuan dan } \\
\text { pengalaman }\end{array}$ & 21 & Ordinal & Kuesioner \\
\hline & \multirow{2}{*}{$\begin{array}{l}\text { Kewajiban } \\
\text { sosial }\end{array}$} & $\begin{array}{l}\text { Profesi auditor } \\
\text { mampu menjaga } \\
\text { kekayaan negara } \\
\text { dan masyarakat }\end{array}$ & 22 & Ordinal & Kuesioner \\
\hline & & $\begin{array}{l}\text { Profesi auditor } \\
\text { menjadi satu- } \\
\text { satunya profesi } \\
\text { yang menciptakan } \\
\text { transparansi }\end{array}$ & 23 & Ordinal & Kuesioner \\
\hline
\end{tabular}




\begin{tabular}{|c|c|c|c|c|c|}
\hline Variabel & Dimensi & Indikator & Item & Skala & Sumber Data \\
\hline & Kemandirian & $\begin{array}{l}\text { Pernyataan } \\
\text { pendapat atas } \\
\text { laporan keuangan } \\
\text { tidak mendapat } \\
\text { tekanan dari } \\
\text { siapapun } \\
\end{array}$ & 24 & Ordinal & Kuesioner \\
\hline & $\begin{array}{l}\text { Keyakinan } \\
\text { terhadap } \\
\text { profesi }\end{array}$ & $\begin{array}{l}\text { Mendapat kepuasan } \\
\text { sebagai auditor }\end{array}$ & 25 & Ordinal & Kuesioner \\
\hline & $\begin{array}{c}\text { Hubungan } \\
\text { dengan rekan } \\
\text { seprofesi } \\
\end{array}$ & Organisasi auditor & 26 & Ordinal & Kuesioner \\
\hline \multirow{11}{*}{$\begin{array}{c}\text { Reputasi Perusahaan } \\
\text { Klien } \\
\left(\mathrm{X}_{4}\right) \\
\text { Spencer }(1974: 90), \\
\text { Barney }(1991: 443), \\
\text { Hannon }(1992: 190), \\
\text { Larkin } \\
\text { (2003;117),dll }\end{array}$} & \multirow[t]{6}{*}{$\begin{array}{l}\text { Kredibilitas } \\
\text { (credibility) }\end{array}$} & $\begin{array}{l}\text { Tingkat kepatuhan } \\
\text { karyawan pada } \\
\text { CEO }\end{array}$ & 27 & Ordinal & Kuesioner \\
\hline & & $\begin{array}{l}\text { Tingkat kengganan } \\
\text { dan resistensi } \\
\text { terhadap CEO }\end{array}$ & 28 & Ordinal & Kuesioner \\
\hline & & $\begin{array}{l}\text { Keterlibatan dalam } \\
\text { masalah hukum }\end{array}$ & 29 & Ordinal & Kuesioner \\
\hline & & $\begin{array}{l}\text { Frekwensi CEO } \\
\text { mendapat teguran } \\
\text { tertulis }\end{array}$ & 30 & Ordinal & Kuesioner \\
\hline & & $\begin{array}{l}\text { Aktivitas sosial } \\
\text { CEO }\end{array}$ & 31 & Ordinal & Kuesioner \\
\hline & & $\begin{array}{l}\text { Jabatan dalam } \\
\text { organisasi }\end{array}$ & 32 & Ordinal & Kuesioner \\
\hline & \multirow{5}{*}{$\begin{array}{c}\text { Kecakapan } \\
\text { Manajerial } \\
\text { (managerial } \\
\text { skill) }\end{array}$} & $\begin{array}{l}\text { Tingkat } \\
\text { kepentingan visi, } \\
\text { misi, bagi CEO }\end{array}$ & 33 & Ordinal & Kuesioner \\
\hline & & $\begin{array}{l}\text { Cara penyusunan } \\
\text { visi, misi, dan } \\
\text { strategi bagi CEO }\end{array}$ & 34 & Ordinal & Kuesioner \\
\hline & & $\begin{array}{l}\text { Kesesuaian } \\
\text { implementasi } \\
\text { program-program } \\
\text { dengan visi, misi } \\
\end{array}$ & 35 & Ordinal & Kuesioner \\
\hline & & $\begin{array}{l}\text { Pencanangan } \\
\text { program } \\
\text { pencapaian visi, } \\
\text { misi }\end{array}$ & 36 & Ordinal & Kuesioner \\
\hline & & $\begin{array}{l}\text { Alat ukur target } \\
\text { yang jelas dalam } \\
\text { manajemen }\end{array}$ & 37 & Ordinal & Kuesioner \\
\hline
\end{tabular}




\begin{tabular}{|c|c|c|c|c|c|}
\hline Variabel & Dimensi & Indikator & Item & Skala & Sumber Data \\
\hline & & $\begin{array}{l}\text { Peningkatan harga } \\
\text { saham setelah IPO }\end{array}$ & 38 & Ordinal & Kuesioner \\
\hline & $\begin{array}{c}\text { Kecakapan } \\
\text { Berkomunikas }\end{array}$ & $\begin{array}{l}\text { Efektivitas CEO } \\
\text { memimpin RUPS }\end{array}$ & 39 & Ordinal & Kuesioner \\
\hline & $\begin{array}{c}\mathrm{i} \\
\text { (communicatio }\end{array}$ & $\begin{array}{l}\text { Sosialisasi visi dan } \\
\text { misi oleh CEO }\end{array}$ & 40 & Ordinal & Kuesioner \\
\hline & $n$ skill) & $\begin{array}{l}\text { Tingkat } \\
\text { pemahaman } \\
\text { karyawan pada visi } \\
\text { dan misi }\end{array}$ & 41 & Ordinal & Kuesioner \\
\hline & & $\begin{array}{l}\text { Penjelasan } \\
\text { pertanggungjawaba } \\
\text { n CEO pada RUPS }\end{array}$ & 42 & Ordinal & Kuesioner \\
\hline & & $\begin{array}{l}\text { Exposure CEO di } \\
\text { media masa }\end{array}$ & 43 & Ordinal & Kuesioner \\
\hline \multirow{2}{*}{$\begin{array}{c}\text { Opini Audit Going } \\
\text { concern } \\
\text { (Y) } \\
\text { Chen, dan Church } \\
\text { (1992), } \\
\text { Arens (1997), } \\
\text { Indira, dan Ella } \\
\text { (2008), } \\
\text { SPAP 2011, dll }\end{array}$} & \multirow[t]{2}{*}{$\begin{array}{c}\text { Tanggung } \\
\text { jawab auditor }\end{array}$} & $\begin{array}{l}\text { Kemampuan entitas } \\
\text { dalam } \\
\text { mempertahankan } \\
\text { kelangsungan hidup }\end{array}$ & $44-46$ & Ordinal & Kuesioner \\
\hline & & $\begin{array}{l}\text { Ketidakpastian } \\
\text { siginifikan atas } \\
\text { kelangsungan hidup } \\
\text { entitas }\end{array}$ & $47-49$ & Ordinal & Kuesioner \\
\hline
\end{tabular}

Sumber : data di olah sendiri

\section{Metode Penarikan Sampel}

Pada penelitian ini akan menggunakan probability sampling yaitu Simple Random Sampling (Sampling Random) dengan rumus Jacob Cohen sebagai berikut:

Keterangan :

$$
\mathrm{N}=\mathrm{L} / \mathrm{F}^{2}+\mathrm{u}+1
$$

$\mathrm{N} \quad=$ Ukuran populasi

$\mathrm{F}^{2} \quad=$ Effect size

$\mathrm{u} \quad=$ Banyaknya ubahan yang terkait dalam penelitian

$\mathrm{L}=$ Fungsi power dari u, diperoleh dari tabel, t.s. $1 \%$.

Berdasarkan rumus Jacob Cohen dapat dihitung nilai power of freedom 0,95 dengan $\mathrm{F}^{2}$ sebesar 0,1 sedangkan $u$ adalah banyaknya variabel bebas.

$$
\begin{aligned}
\mathrm{N} & =\mathrm{L} / \mathrm{F}^{2}+\mathrm{u}+1 \\
\mathrm{~N} & =0.1828 / 0.1+4+1 \\
& =6.828 \times 95 \\
& =648.66
\end{aligned}
$$

Hasil angka 648.66 menunjukan jumlah populasi pada KAP Big Four di Indonesia. Tahap berikutnya dilakukan perhitungan jumlah sampel dengan menggunakan tabel Krejcie dan 
Morgan (1970) dalam Uma Sekaran (1992) pada angka kisaran 650 sehingga jumlah sampel sebesar 242; di mana sampel akan dialokasikan kepada masing-masing KAP Big Four di Indonesia. Berdasarkan jumlah alokasi purposive sampling. Dasar pembagiannya menggunakan jumlah data pegawai tahun 2019.

\section{HASIL PENELITIAN}

Metode analisis menggunakan regresi berganda untuk mengetahui pengaruh secara parsial dan simultan. Hasil penelitian terlebih dahulu dilakukan uji validitas, reliabilitas, dan transformasi data ordinal ke interval.

Tabel 4. Uji realibitas Cronbach's Alpha (0.60), dan validitas Product moment (0.219)

\begin{tabular}{|c|l|c|c|}
\hline $\begin{array}{c}\text { Nom } \\
\text { or }\end{array}$ & \multicolumn{1}{|c|}{ Variabel } & $\begin{array}{c}\text { Cronbach's } \\
\text { Alpha } \\
(0.60)\end{array}$ & $\begin{array}{c}\text { Product } \\
\text { moment } \\
(0.219)\end{array}$ \\
\hline 1 & Solidaritas sosial $\left(\mathrm{X}_{1}\right)$ & 0,863 & $0,551-0,680$ \\
\hline 2 & Kompetensi auditor $\left(\mathrm{X}_{2}\right)$ & 0,874 & $0,858-0,875$ \\
\hline 3 & Profesionalisme auditor $\left(\mathrm{X}_{3}\right)$ & 0,851 & $0,817-0,850$ \\
\hline 4 & $\begin{array}{l}\text { Reputasi perusahaan klien } \\
\left(\mathrm{X}_{4}\right)\end{array}$ & 0,907 & $0,898-0,904$ \\
\hline 5 & $\begin{array}{l}\text { Opini audit going concern } \\
(\mathrm{Y})\end{array}$ & 0,768 & $0,694-0,775$ \\
\hline
\end{tabular}

Berdasarkan output SPSS versi 24 dapat dilakukan penyusunan model pengujian hipotesis melalui bentuk persamaan uji hipotesis Pengaruh Solidaritas Sosial ( $\left.\mathrm{X}_{1}\right)$, Kompetensi Auditor $\left(\mathrm{X}_{2}\right)$, Profesionalisme Auditor $\left(\mathrm{X}_{3}\right)$, Reputasi Perusahaan Klien $\left(\mathrm{X}_{4}\right)$ Terhadap Opini Audit Going Concern (Y) sebesar 36,6\%, dan $63.4 \%$ dipengaruhi oleh variabel lain di luar model penelitian.

Model Path Analyis: Pengaruh Solidaritas Sosial $\left(\mathbf{X}_{1}\right)$, Kompetensi Avdfor $\left(\mathbf{X}_{2}\right)$. Profecionalisme Auditior $\left(\mathrm{X}_{1}\right)$, Reputasi Peruahaan Klien $\left(\mathrm{X}_{4}\right)$ Terhadap Opini dudit Gotng Concern ( $\mathrm{Y}$ ) baik Secara Parsial maupun Sirmultan

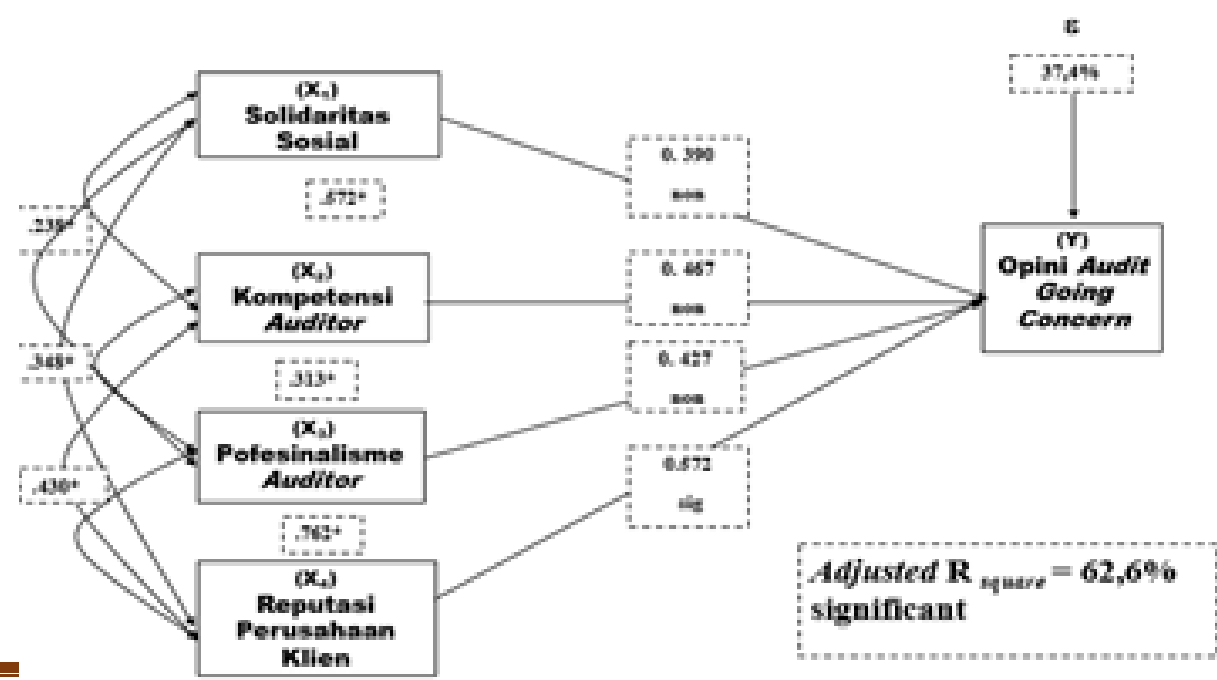




\section{Gambar 2. Model Path Analisis Pengaruh Solidaritas Sosial (X), Kompetensi Auditor (X), Profesionalisme Auditor (X), Reputasi Perusahaan Klien ( $\left.\mathbf{X}_{4}\right)$ Terhadap Opini Audit Going Concern (Y)}

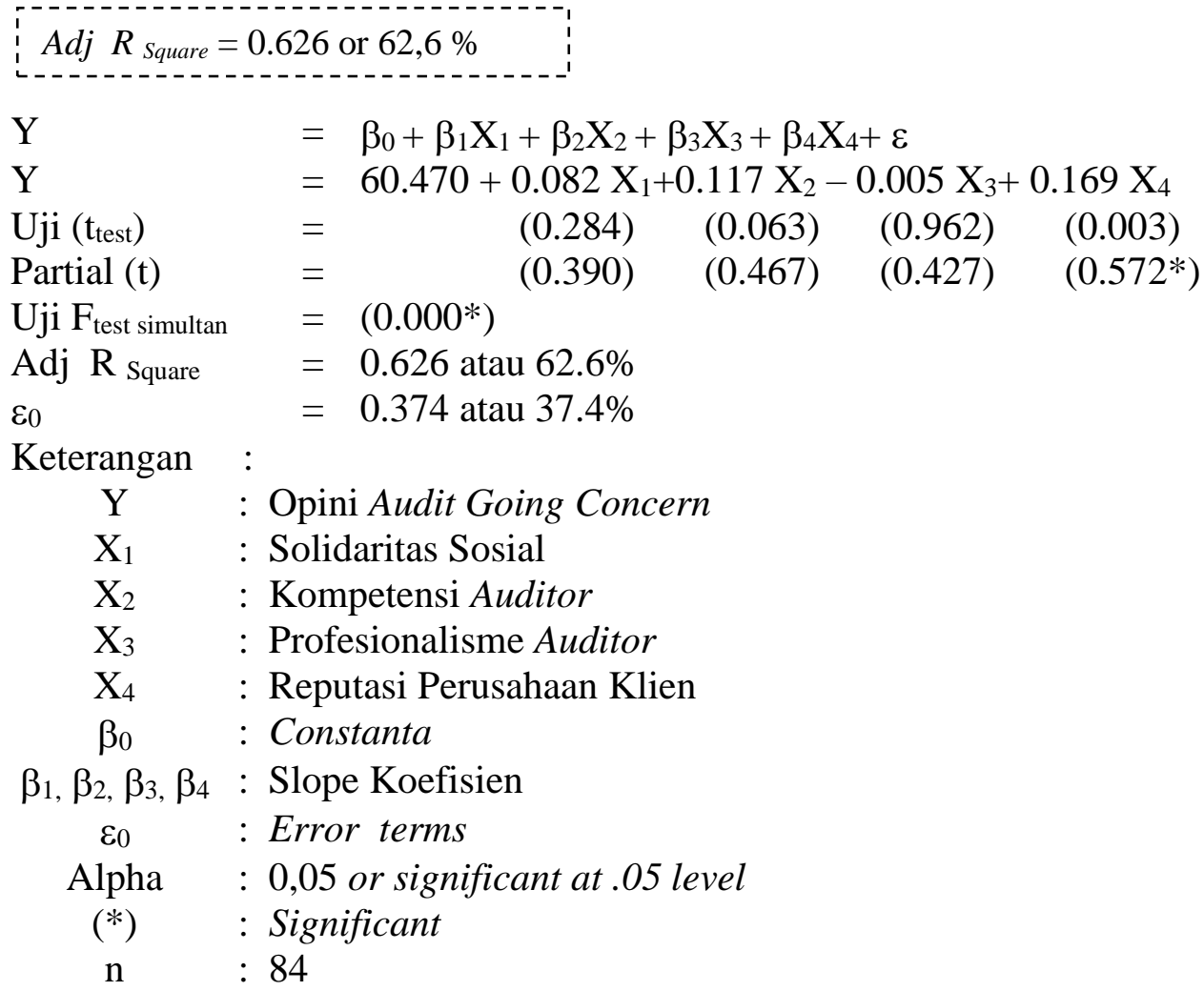

\section{Hasil Temuan dalam Penelitian}

Terdapat pengaruh positif antara Solidaritas Sosial ( $\left.\mathrm{X}_{1}\right)$, konsep Solidaritas Sosial ( $\left.\mathrm{X}_{1}\right)$; Durkheim (1986:181), Karl Marx (1818-1883), Herbert Spencer (1820-1903), Marx Weber (1864-1920) mempunyai dimensi keterikatan bersama, dengan tiga indikator pertimbangan moral, kepercayaan terhadap klien, pengalaman bersama klien, Kompetensi Auditor $\left(\mathrm{X}_{2}\right)$, pada konsep Douglas McGregor (1906-1964), Abraham H. Maslow (1908-1970), Victor Vroom (1964), Frederick Herzberg (1966), Spencer and Spencer (1993)mempunyai dimensi (a) Knowledge Component, sedangkan indikatornya pengetahuan umum dan khusus, memperoleh fakta-fakta yang relevan (b) Psychological traits, sedangkan indikatornya tanggung jawab, kemampuan bekerja sama (c) Cognitive abilities, sedangkan indikatornya mampu berpikir secara sistematis, memiliki kemampuan analis (d) Decision strategies, sedangkan indikatornya objektifitas pengambilan keputusan, independensi pengambilan keputusan (e) Task analysis, sedangkan indikatornya skeptisme yang professional, kemampuan teknis yang memadai, Profesionalisme Auditor (X 3 ), konsep Hall, (1968:95), Kalbers, dan Fogarty (1995:72), SPAP (2011) pada dimensi (a) pengabdian terhadap profesi, sedangkan indikatornya tetap teguh pada profesi auditor, menggunakan pengetahuan, kemampuan dan pengalaman (b) kewajiban sosial, 
sedangkan indikatornya profesi auditor mampu menjaga kekayaan negara dan masyarakat, profesi auditor menjadi satu-satunya profesi yang menciptakan transparansi (c) kemandirian, sedangkan indikatornya pernyataan pendapat atas laporan keuangan tidak mendapat tekanan dari siapapun (d) keyakinan terhadap profesi, sedangkan indikatornya mendapat kepuasan sebagai auditor (e) hubungan dengan rekan seprofesi, sedangkan indikatornya organisasi auditor, dan Reputasi Perusahaan Klien (X4), Spencer (1974:90), Barney (1991:443), Hannon (1992:190), Larkin $(2003 ; 117)$, mempunyai dimensi (a) Kredibilitas (credibility), sedangkan indikatornya tingkat kepatuhan karyawan pada CEO, tingkat kengganan dan resistensi terhadap CEO, keterlibatan dalam masalah hukum, frekwensi CEO mendapat teguran tertulis, aktivitas sosial CEO, jabatan dalam organisasi (b) kecakapan manajerial (managerial skill), sedangkan indikatornya tingkat kepentingan visi, misi, bagi CEO, cara penyusunan visi, misi, dan strategi bagi CEO, kesesuaian implementasi program-program dengan visi, misi, pencanangan program pencapaian visi, misi, alat ukur target yang jelas dalam manajemen, peningkatan harga saham setelah IPO (c) Kecakapan Berkomunikasi (communication skill), sedangkan indikatornya efektivitas CEO memimpin RUPS, sosialisasi visi dan misi oleh CEO, tingkat pemahaman karyawan pada visi dan misi, penjelasan pertanggungjawaban CEO pada RUPS, exposure CEO di media masa terhadap Opini Audit Going concern (Y), konsep Chen, dan Church (1992), Arens (1997), Indira, dan Ella (2008), SPAP 2011 mempunyai dimensi tanggung jawab auditor, dengan dua indikator kemampuan entitas dalam mempertahankan kelangsungan hidup, ketidakpastian memiliki pengaruh siginifikan sebesar 0.626 atau $62.6 \%$.

\section{Simpulan}

Pengujian statistik hipotesis pertama terdapat pengaruh solidaritas sosial, kompetensi auditor, profesionalisme auditor, reputasi perusahaan klien terhadap opini audit going concern secara parsial dapat disimpulkan masing-masing : (a) pengaruh solidaritas sosial terhadap opini audit going concern non signifikan, (b) pengaruh kompetensi auditor terhadap opini audit going concern non signifikan, (c) pengaruh profesionalisme auditor terhadap opini audit going concern non signifikan, (d) pengaruh reputasi perusahaan klien terhadap opini audit going concern signifikan. Pengujian statistik hipotesis kedua terdapat pengaruh solidaritas sosial, kompetensi auditor, profesionalisme auditor, reputasi perusahaan klien terhadap opini audit going concern secara simultan dapat disimpulkan mempunyai pengaruh positif dan signifikan sebesar $62.6 \%$ sedangkan sisanya $37.4 \%$ dipengaruhi variabel lain di luar model penelitian.

\section{DAFTAR PUSTAKA}

Aiken, Lewis R. (1994). Psychological Testing and Assessment,(Eight Edition), Boston: Allyn and Bacon.

A, Alvin Arens dan Jammes K. Loebbecke,1999.Auditing (suatu pendekatan terpadu).Edisi Keempat,Penerbit Erlangga,Jakarta.

Arens, Alvin A, Beasley, Mark S. dan Elder, Randal J. (2008). Auditing and Assurance Services An Integrated Approach. $12^{\text {th }}$ ed. New Jersey : Pearson Prentice Hall

Anastasi. Anne and Urbina, Susana. (1997). Psicoholological Testing. (Seventh Edition). New Jersey: Prentice-Hall, Inc.

Amrit Tiwana., 2001., The Essential Guide To Knowledge Management., Upper Saddle River : Prentice Hall PTR. 
Allen, William., Louis K Bragraw.Jr,. 1982. Social Forces and The Manager, Reading and Case.,New York: Mc Graw Hill-Inc

Assessment Systems Corporation. (1984). User's Manual for the MiicroCat Testing System,USA.

Atkinson, John W. (1978). Personality Motivation and Achievement. Sashington. Hemisphere Publishing Corporation.

Bahm, Archie, J., 1980., "What Is Science”, Reprinted from my Axiology; The Science Of Values

Baggini, Julian., 2002., Philosophy: Key Themes., New York: Palgrave Macmillan.

Baron. David.,2000., Business and Its Enviriment. Third Edition: New Jersey., New Jersey.

Belkaoui, Ahmed, R., 1993., Accounting Theory., $3^{\text {ed }}$ edition., Cambridge : The University Press.

Berkson, William, Wettersten., 1994., Learning From Error (Karl Popper's Psychology of Learning: Open Court Publising Company.

Bejar, Isaac I. (1983). Introduction to Item Response Theory and Their ${ }^{-}$Assumptions. Hambleton, Ronald K. (Editor). Applications of Item Response Theory. Canada: Educational Research Institute of British Columbia.

Berk, M Görkhan.(2003). “Assessment of the Effect of an External Factor for Dwelling Occupants' Satisfaction: Access to Basic Activities". Methodologies in Housing Research Conference. 22-24 September, Sweden, Stockholm.

Bernard, M Bass, Bruce J Avilio, 1994., Improving Organizational Effectiveness, Through Tranformational Leadership

Bloom, Elgers., 1987., Accounting Theory and Policy Second Edition., San Diego : Harcourt Brace Jovanovich, Publishers

Boynton, William C., Kell, Walter., 2001., Modern Auditing., Sixth Edition., New York: John Willy and Sons.

Bruning, James L. and Kintz, B. L. (1987). Computational Handbook of Statistics. Third Edition. Illinois: Scott, Foresman and Company

Carl G. Hempel., 2004., Pengantar Filsafat Ilmu Alam., Yogyakarta : Pustaka Pelajar.

Cornel, B. and Shapiro A. .,1987., Corporate Stakeholder and Corporate Finance., Financial Management., 16:5-14

Corporate Governance Perception Index, 2007., Laporan hasil riset dan pemeringkatan.

Carroll, Archie B., Ann K Buchholts., 2009.., Business and Society: Ethics and Stakeholders Management., Fifth Edition., New York: Thomson South Western.

Cornelius, Ed. 2003. Leading a culture ready for change, Executive Excellence (EEX), Vol. 20, Iss. 7, p. 15.

Charles Guignon dan David R. Hiley, Richard Rorty., 2003.,Cambridge, Cambridge University Press,

Chorafas, Dimitris., 1995., Chaos theory in Financial Market., New Delhi: S Chand and Company Ltd. 
Clutterbuck ,David. Peter Waine., 1994., The Independent Board Director, Selecting and Using the Best Non Executive Directors to Benefit Your Business.,London: McGraw Hill, Inc.

Crocker, L. \& Algina, J. (1986). Introduction to Classical and Modern Test, Theory_. New York: Holt, Rinehart and Winston, Inc

Denzin. N. K. \& Lincoln. Y. S. (Editors) (1994). Handbook of Qualitative Research. London. New Delhi: Sage.

Delfgaauw. B. (1987). Filsafat Abad 20 (Alih Bahasa oleh Soeyono Soemargono). Yogyakarta: Tiara Wacana Jogjakarta.

Durkheim, Emile. (1964).The Division of Labor in Society.translated by George Simpson.New York : Free Press

Dewey, John,.1997.,How We Think., Mineola New York: Dover Publications, Inc.

Donald B. Calne., 2005., Batas Nalar., Jakarta : Kepustakaan Populer Gramedia.

Ebel, Robert L, and Frisbie, David A. Essentials of Educatiornul Measurement. New Jersey: Prentice Hall, 1991.

Edmund Husserl., 1970., Logical Investigations., Volume One., New York : The Humanities Press.

., 1970., Aristippos ( $\pm 433-355$ SM) Logical Investigations., Volume One., New York : The Humanities Press.

., 1970., Epikuros (341-270 SM), Logical Investigations., Volume One., New York : The Humanities Press.

1970.,Aristoteles (384-322 SM). Logical Investigations., Volume One., New York : The Humanities Press.

., 1970.,Jeremy Bentham (1748-1832) Logical Investigations., Volume One., New York :

The Humanities Press.

_..., 1970.,John Stuart Mill (1806-1873), Logical Investigations., Volume One., New York :

The Humanities Press.

_..,. 1970.,Immanuel Kant (1724-1804). Logical Investigations., Volume One., New York : The

Humanities Press.

_..,. 1970.,Immanuel Kant, (1724-1804), Logical Investigations., Volume One., New York :

The Humanities Press.

_..,. 1970.,Jeremy Bentham (1748-1832), Logical Investigations., Volume One., New York :

The Humanities Press.

__.,., 1970.,John Stuart Mill (1806 -1873), Logical Investigations., Volume One., New York :

The Humanities Press.

_..,., 1970.,John Locke (1632-1704). Logical Investigations., Volume One., New York : The

Humanities Press.

.,., 1970.,Plato (429-327SM), Logical Investigations., Volume One., New York : The

Humanities Press. 
., 1970., John Locke (1632-1704), Logical Investigations., Volume One., New York : The Humanities Press.

.,., 1970.,Adam Smith (1723-1789), Logical Investigations., Volume One., New York : The Humanities Press.

, 1970.,George W.F. Hegel (1770-1831), Logical Investigations., Volume One., New York :

The Humanities Press.

1970.,Karl Marx (1818-1883), Logical Investigations., Volume One., New York : The

Humanities Press.

, 1970.,Hannah Arendt (1906-1975). Logical Investigations., Volume One., New York : The

Humanities Press.

1970.,George W.F. Hegel, Logical Investigations., Volume One., New York : The Humanities Press.

Erdward Synan, “The Four 'Senses' and Four Exegetes," dalam J. D. McAuliffe, B. D. Walfish, dan J. W. Goering, With Reverence for the Word: Medieval Scriptural Exegesis in Judaism, Christianity, and Islam (Oxford: Oxford University Press, 2003), hlm. 225236.

Ewing, A.C., 1962., The Fundamental Questions of Philosopy., New York., Collier Books.

F. Budi Hardiman., 2004., Filsafat Modern Dari Machiavelli sampai Nietzsche., Jakarta : Gramedia Pustaka Utama.

Gadamer, "Text and Interpretation", dalam B. R. Wachterhauser (ed.), Hermeneutics and Modern Philosophy (New York: Albany State University of New York Press, 1986), hlm. 396.

Geletkanycz, Marta A. 1997. The Salience of Culture's Consequences: The Effects of Cultural Values on Top Executive Commitment to the Status Quo, Strategic Management Journal, Vol.18, No. 8, p.p. 615- 634.

Glaser, S.R., S. Zamanou, and K. Hacker. 1987. Interpreting Organizational Culture, Management Communication Quarterly.

Gordon, G.G., and W.M. Cummins. 1979. Managing Management Climate, Lexington MA.

Glass, Gene V. and Stanley, Julian C. (1970). Statistical Methods in Education and Psychology.

New Jersey: Prentice Hall, Inc.

Guba. E. G. (1990). The Paradigm Dialog. London. New Delhi: Sage.

Gray, Iain dan Manson, Stuart. (2008). The Audit Process Principles, Practice And Cases. $4^{\text {th }}$ ed.

London: South Western Cengange Learning

Greertz. C. (1992). Tafsir Kebudayaan. (Alih Bahasa oleh Fransisco Budi Hardiman). Yogyakarta: Penerbit Kanisius.

Gujarati, Domodar.,2003., Basic Econometrics., Second Edition,. New York : Mc. Graw Hill International Edition.

Hair, J. F.; Anderson, R. E., Tatham, R. L., and Black, W. C. (1998). Multivariate Data, Analysis. New Jersey. Prentice-I-lall International, Inc. 
Haladyna, Thomas M. (1994). Developing and Validating Multiple-Choice Test Items. New Jersey: Lawrence Erlbaum Associates, Publishers.

Hall, Richard.(1968).Professionalism and Bureaucratization, American Sosiological Review,(pp 33:92-104)

Hambleton, Ronald K.; Swaminathan. H.; and Rogers, H. Jane. (1991). Fundamentals of Item Response Theory. California: Sage Publications, The International Professional Publishers.

Harman, Harry H. (1970). Modern Factor Analysis (Third Edition Revised). Chicago: The University of Chicago Press.

Hatch, Mary J0. 1993. The Dynamics of Orgnizational Culture, Academy of: Management Review, Vol. 18, No. 4, p.p. 657- 693.

Hennessey, J. Thomas, Jr. 1998. Reinventing Government: Does Leadership make the difference?, Public Administration Review, Vol. 58, No. 6, p.p. 522- 532.

Hofstede, Geert. 1986. Culture's Consequences, International Differences in Work-Related Values, New Delhi: Sage Publication, Beverly Hills, London.

Heer, Wim F. de and Ger Moritz.(2000)."Data Quality Problem in Travel Survey. An International Overview”. Workshop on Respondet Issue: Sampling, Weighting and Nonresponse. Statistic Netherland.

Holland. PW \& Thaycr. DT (1988). Test Validity. New Jersey: Lawrence Erlbaum Associates, Publishers.

Izard, John. (1995).Trial Testing and Item Analysis (Module (A). Australia: Australian Council Ibr Pdtrcallonal Research, UNESCO

James Copeland, 2003, Post Enron Challenges for Auditing Profession : Accountability, Journal Vital Speeches of Day, New York.

Jean Grondin, Introduction to Philosophical Hermeneutics (New Haven: Yale University Press, 1991), hlm. 104.

J. Donald Walters., 2003., Crises in Modern Thought., Jakarta : Gramedia Pustaka Utama.

Johnson, Doyle Paul.(1988).Teori Sosiologi Klasik.Terjemahan Robert M.Z. Lawang.Jakarta:PT Gramedia

Joreskog, Karl and Sorboni, Dag. (1996). PRELIS2:User's Reference Guide. Chicago: Scientific Software Internasional, Inc.

Joreskog, Karl G and Sorbom, Dag, (1989). LISREL, 7 User's Reference Guide, First Edition. IJSA: Scientific Software, Inc.

Jujun S. Suriasumantri., 2003., Filsafat Ilmu Sebuah Pengantar Populer., Jakarta : Pustaka Sinar Harapan.

Jacques Derrida (1930-2004), F. Budi Hardiman., 2004., Filsafat Modern Dari Machiavelli sampai Nietzsche., Jakarta : Gramedia Pustaka Utama.

Jean Paul Sartre (1905-1980). F. Budi Hardiman., 2004., Filsafat Modern Dari Machiavelli sampai Nietzsche., Jakarta : Gramedia Pustaka Utama. 
J. Sudarminta., 2002., Epistemologi Dasar Pengantar Filsafat Pengetahuan., Yogyakarta : Kanisius.

Hempel, Carl G.,1966 Philosophy of Natural Science.Printice Hall. Inc., Englewood Cliffs. Hendriksen, Eldon, S., 1990., Accounting Theory., Fourth Edition., Illinois: Richard Irwin Inc. Hofstede, G. (1980). Culture's Consequences: International differences in work-related values. Beverly Hills, Calif.: Sage.

Jansen H Sinamo., 2005., 8 Etos Kerja Profesional., Jakarta: Insitut Darma Mahardika.

Johnson, Glenn., 19_. Research Methodology For Economists: Philosopy and Practice., New York: Macmillan Publishing Company.

Kant, Immanuel, 1989, "Good Will, Duty, and the Categorical Imperative," ed. Anthony Serafini, Ethics and Social Concern New York: Paragon House Publishers

K. Bertens., 1999., Sejarah Filsafat Yunani., Yogyakarta : Kanisisus.

Killman, R.H., Saxton, M.J., and Serpa, R. 1986. Issues in Understanding and changing culture, California Management Review, No.2, pp. 87- 94.

Lakatos, Imre., Allan Musgrave., 1970., Criticism and the Growth of Knowledge.,Cambridge

Linn, Robert L. and Gronlund, Norman E. (1995). Measurement and Assessment in teaching

(Seventh Edition). Ohio: Merrill, an immprint of Prentice Hall.

Losh, Susan Carol.(2000). “Types of Error and Basic Sampling Designs”. Lecture Handout EDF 5481 Methods of Educational Research. Fall.

Ludington, Paul W.(2003).Stratification of Primary Sampling Units for the Current Population Survey Using Computer Intensive Methods. US Bureau of Cencus. Wahingtoon DC.

Lord, F. M. (1952). A Theory f Test Scores. USA: Educational Testing Service.

Luthans, Fred,. Richard Hodgetts, Kenneth Thomson.,1980., Social Issues In Business., Third Edition.,New York., Macmillan Publishing, Co, Inc.

Manuel G. Velasquez., 1992., Business Ethics., $3^{\text {ed }}$ edition., New Jersey : Prentice Hall.

Mark B. Woodhouse., 2000., Berfilsafat., Yogyakarta : Kanisius.

McDonald, Roderich P. (1999). Test Theory: A Unified Treatment. New Jersey: Larvrence Erbaum Associates, Publishers.

Mc. Carthy. T. (2006). Teori Kritis Jürgen Habermas (Alih Bahasa oleh Nurhadi).

Miles. M. B. \& Huberman. A. M. (1992). Analisis Data Kualitatif (Alih Bahasa oleh Tjetjep Rohendi Rohidi). Jakarta. UI. Press.

and Apes.,

Mitchell, Peter.,1997. Introduction to Theory of Mind: Children, Autism and Apes., London. New York. Sydney, Auckland: Arnold.

Moeller, Robert., 2004.. Sarbanes Oxley and New Internal Auditing Rules: New Jersey., John Wiley and Sons

Peter Mitchell.,1997., Introduction To Theory Of Mind., London : A Member of The Hodder Headline Group. 
Plunkett, Warren R., Raymond F. Affner. 1994. Introduction to Management, Fifth Edition, USA: International Thompson Publishing.

Popham, James W. (1995). Classroom Assessment: What Teachers Need to Know. Boston: Allyn and Bacon.

_.., Philosophy and The Mirror of Nature, 2003., Cambridge, Cambridge University Press.

SAK Ikatan Akuntan Indonesia, Standar Akuntansi Keuangan. Per Juni 1999,. Jakarta: Salemba Empat.

Sarros, James C.m Judy Gray, laian L. Densten. 2002. Leadership and its Impact on Organizational Culture, International Journal of Business Studios, Vol. 10, No. 2, p.p. $1-26$.

Silverman. D. (1997). Qualitative Research: Theory, Method and Practice. London: Sage.

Smith. J. A. (2006). Qualitative Psychology A Practical Guide to Research Methods. London: Sage.

Solomon, Jill., 2007., Corporate Governance and Accountability., Second Edition., San Francisco: John Wiley, and Sons, Ltd.

Sonny Keraf, Mikhael Dua,, 2001., Ilmu Pengetahuan, Sebuah Tinjauan Filosofis., Yogyakarta: Kanisius.

Snow, Rob E., John D. Hutchenson, Jr., and James E. Prather.(1979).Using Reputational Sampling to Identify Residential Clusters of Minorities. Center for Urban Research and Service.

Suherly, 2001., Metodologi Penelitian Ilmu Ekonomi, Program Pascasarjana Universitas Padjadjaran Bandung.

Sukrisno Agoes, Pidato Pengukuhan Guru Besar, Fakultas Ekonomi- Universitas Tarumanegara, 2007

Wolk, Harry .I. and Michael G. Tearney., 1997., Accounting Theory : A Conceptual and Institutional Approach., Fourth Edition,. Ohio: South Western College Publishing.

Yukl, Gary A. 1998. Leadership in Organizations, 3e, Edisi Bahasa Indonesia, Jakarta: Prehhallindo.

Zabihollah, Razee, 2002, Financial Statement Fraud : Prevention and Detection, John Wiley \& Sons, New York.

Zainal Abidin., 2006., Filsafat Manusia., Bandung : PT Remaja Rosdakarya

Zikmund, William., 1997., Business Research Methods., fifth Edition., California; The Dryden Press.

Journals:

Amit dan Shoemaker,., 1992., Alternative Accounting Methods, Informations Asymentry and Liquidity : Theory and Evidence., “The Accounting Review vol. 71 July . p. 20-66.

Abdulmuhammadi, \& A Wright.(1987).Examination of the Effect of Experience and Tax Complexity of Audit Judgement. The Accounting review. Vol LXII No.1.pp 1-13 
Akerlof (1970).., Initial Public Offering, Accounting Choice \& Earnings management. Contemporary Accounting Research., 10 (January).p. 127-143.

Ashton, A.(1991).Experience and Error Frequency Knowledge as Potencial Determinan of Audit Expertise. The Accounting Review,66,2,218

Baiman, Stanly., 1982., "Agency Research in Management Accounting: A Survey", . Journal of Accounting Literature., p.159.

Bamber, Bhattacharya., Sunder Kang and Krishna R. Kumar., 1998., “Accounting Earnings and Excecutive Compensation : The Role of Earnings Persistence",. Journal of Accounting and Economics,. p. 1-13.

Burgstahler, David and Ilia Dichev, 1997., Earnings management To Avoid Earnings Decreases And Losses., Journal of Accounting and Economics., p. 99-126.

Bushman, Robert., Raffi Indjejikian and Abbie Smith., 1996., CEO Compensation: The Role of Individual Performance Evaluation., Journal of Accounting and Economics.p. 161-193.

Christiawan, Y.J. (2002). Kompetensi dan independensi akuntan publik: refleksi hasil penelitian empiris. Journal Directory : Kumpulan Jurnal Akuntansi dan Keuangan Unika Petra. Volume 4 (02)

Chen, Kevin., and Chi Wen Javons Lee., 1995., "Executive Bonus Plans and Accounting Tradeoff: The Case of the Oil and Gas Industry”, Industry Accounting Review. Vol. 70 No. 1 (January).p. 49-68.

Carcello et al., (1992), The Nature of Firms", . Economica Vol. 4.. p. 386-405.

Carey dan Simnett 2006, , A Fremework for Developing the Objectives of Financial Statement., American Institute of Certified Public Accountats., vol. 2., p. 30-35.

Christian von Weizsaker (Williamson, 1985:49):, The Effects of Debt Covenants And Political Costs On the Choice of Accounting Method: The Case Of Accounting For R \& D cost., Journal of Accounting and Economics p. 195-211.

Caves dan Porter, (1977:7 ; “A Note on Income Smoothing in The Chemical Industry”,Journal Accounting Research., p. 253-259.

De Angelo (1981); "Accounting Choice in Troublend Companies", Journal of Accounting and Economics 17 p. 133-144

Dobson(1989:26)., Accounting Earnings and cash Flows as Measures of Firm Performance

: The Role of Accounting Accruals., Journal of Accounting and Economics., p., $3-42$.

Dowling (2001:221) ., Debt Covenant Violation and Manipulation of Accruals., Journal of Accounting and Economics., p. 145-176.

Dreyfus dan Dreyfus ., 1997., "Smoothing Income Anticipation Of Future Earnings"., Journal of Accounting and Economics (July). p. 115-139.

Dhaliwal, Dan S., 1985., "The Effect of Firms Capital Structure on the Choice Of Accounting Methods", The Accounting Review Vol. 55 p. 78-84. 
Fama, Eugene .F., 1980., "Agency Problems and the Theory of the Firms", Journal of Political Economy, vol 2.,p. 288-307.

Hendro Wahyudi. (2006).Pengaruh profesionalisme Auditor terhadap Tingkat Materialitas Dalam Proses Pengauditan Laporan Keuangan.” Jurnal SNA IX.Malang

Harris Interactive, Charles Fombrun dan Cees van Riel. ., 1992., "An Examination od Factors Influencing Financial Reporting Decisions Of Small Business Owner-Managers”, Behavioral Research in Accounting Vol. 10 p. 21-31.

Jones, Frederick., 1991., “Earnings management During Import Relief Investigations”., Journal of Accounting Research 29. P. 193-228.

Kamin, Y., June., and Lawrence Ronen ., 1978., "The Smoothing of Income Numbers: Some Empirical Evidence in Systemetic Differences Among Management Controlled and Owner-Controled Firms", Accounting, Organization and Society 3 No. 2., p. 141-153.

Konfer dan Ackerman (1989), Issues in Testing Earnings management and An Intrumental Variable Approach., Journal Of Accounting Research. , (33)., p. 353-367.

Klein dan Leffler, (1981:29) ; Kelly, Lauren., 1983., The Development of a Positive Theory of Corporate Management's Role in External Financial Reporting., Journal of Accounting Literature. ,p, 111-150.

Kalbers dan Fogarty,1995:72, Political Cost Incentives For Earnings Management in The Cable Television Industry., Journal of Accounting and Economics., p, 309-337.

Koch, Bruce., 1981., "Income Smoothing: An Experiment"., The Accounting Review Vol. LVI No. 3 (July)., p. 574-586.

Lee, Tom, and Marry Stone.(1995).Competence and Independence : The Congenial Twin Of Auditing?.Journal of Business Finance and Accounting.pp1169-1177

Larkin (2003;117), Economic Determinants of Accounting Policy Choice., Journal of Accounting and Economics, p., 87-114.

Saifudin dan Pamudji, Sugeng.(2004).Pengaruh Kompetensi dan Independensi Terhadap Opini Audit Going Concern (studi kueksperimen pada mahasiswa dan auditor). Jurnal Maksi Volume 4

Schroeder et al.,(1986), "Replication of Moses Income Smoothing Test With Canadian \& UK Data”, Journal of Business, Finance and Accounting, (October). P. 1219-1222.

Zimmerman, Jerold., 1980., Positive Research in Accounting., University of Wisconsin., p. 107128.

Masimba, Roderick David., 1990., "The Agency Problem: An Empirical Investigation of Principal Agent Relationshipin Tanzania”, Dissertation., University of Colorado at Boulder., p. 12.

Park, G. Wanghoon., 1991., "The Association Between Management Compensation and Accounting Policy Decisions: An Extension of The Bonus Hypothesis”, Dissertation., University of Colorado at Boulder., p.122. 
Peltier, Rivest Dominic., 1996., "The Determinants of Accounting Choices in Troubled Companies", Dissertation., Cleveland Stated University., p.94..

Pourjalali, Hamid., 1992., "An Improved Test of Positive Accounting Theory : Examination of the Changes in the Amount of Accruals in Response to the Changes in Conctacting Variables", Dissertation., The George Washington University., p. 2. 